\title{
International Journal of General Medicine \& Surgery
}

\author{
Available Online: http://ijgms.edwiserinternational.com
}

\section{Method of Preventive Ultrasound Diagnosis of Venous Thrombosis}

\author{
Igor M. Ignatyev* and Elena E. Fomina
}

${ }^{1}$ Department of Vascular Surgery, Interregional Clinical and Diagnostic Center, Kazan, Russian Federation

${ }^{2}$ Kazan State Medical University, Kazan, Russian Federation

Article info

Received 05 April 2017

Revised 26 April 2017

Published 01 May 2017

*Corresponding author: Igor $\mathrm{M}$. Ignatyev, Department of Vascular Surgery, Interregional Clinical and Diagnostic Center, 12 A, Karbyshev St. 420101, Kazan, Russian Federation, E-mail: imignatiev@rambler.ru

\begin{abstract}
Objective: To develop the method of preventive diagnosis of venous thrombosis using the ultrasound duplex scanning (USDS).

Materials and methods: 306 persons were examined, 146 were patients with acute venous thrombosis, 108 patients - with varicose veins and 52 healthy persons (control group). All participants were examined using USDS and $D$-dimer level was evaluated.

Results: As the result of the conducted research an ultrasound phenomenon of echogenic particles in valvular sinus area (further referred to as spontaneous echo contrast) is described. A classification of this phenomenon is developed; two degrees of spontaneous echo contrast are documented. Spontaneous echo contrast of the 1st degree reflects the fact that the valvular sinus area is the most thrombogenic zone. Spontaneous echo contrast of the 2nd degree is characterized as pathological, it is a prethrombotic state and can serve as one of the earliest predictors of developing venous thrombosis. A high correlation between phenomenon of spontaneous echo contrast of the 2 nd degree, venous thrombosis and $D$ dimer level indicators is determined $(r=0.89, P<0.05)$.

Conclusions: An ultrasound study of valvular sinus is a simple, available and reproducible method of screening and can be applied as a preventive diagnostic of acute venous thrombosis. The results of the investigations permit us to form risk groups of deep vein thrombosis and perform timely prevention of this pathology.
\end{abstract}

Keywords: Thrombosis of deep veins; Preventive ultrasound diagnostics; Ultrasound duplex scanning; Venous valve; Effect of spontaneous echo contrast.

\section{Introduction}

Deep vein thrombosis (DVT) of lower extremities and pulmonary embolism (PE) are major health care problems [1,2]. DVT and PE are approximately 160 and 60 cases per 100000 accordingly every year $[3,4]$.

For indication of these diseases a term of venous thromboembolism (VTE) is used. There is a tendency of growing frequency of VTE. In the US, an estimated 600.000 cases of venous thromboembolism occur annually $[5,6]$.

Prevention of VTE is one of the main issues of contemporary medicine taking into account the difficulty of diagnostics, severe complications of this pathology and considerable economic losses [7]. According to the above-mentioned information, a screening method of early diagnostics of deep vein 
Citation: Ignatyev IM, Fomina EE. Method of Preventive Ultrasound Diagnosis of Venous Thrombosis. Int J Gen Med Surg 2017; 1: 105.

thrombosis, that should satisfy two criteriaobjectivity and availability, is of current importance.

One of the most informative methods of diagnostics of venous thrombosis is ultrasound duplex scanning (USDS). The accuracy of veins femoropopliteal segment is more than $90 \%$, calf veins - from 50 to $90 \%[8]$.

The aim of the study is a development of preventive diagnostics of venous thrombosis with USDS.

\section{Materials and Methods}

The study was comparative. There were three groups of patients: the 1st (main) group comprised 146 patients (146 extremities) with acute thrombosis of veins of lower extremities (77 patients with varicose vein thrombosis and 69-with thrombosis of deep veins), the 2nd (comparison)-108 patients (108 extremities) with varicose veins with different manifestation of chronic venous insufficiency (CVI) and the $3 \mathrm{~d}$ (control)-52 healthy persons (52 extremities). In the first group the age of patients was from 29 to 54 years (mean-41.2 \pm 7.9 years), in the second group - from 27 to 55 years (mean-39.8 \pm 8.1 years), in the third group-from 23 to 56 years (mean$43.8 \pm 7.1$ years). Verification of diagnoses like varicose vein thrombosis, thrombosis of deep veins and varicose veins were based on USDS. The criterion for inclusion to the control group was the absence of ultrasound venous pathology.

All patients were examined with USDS. The study was carried out on HDI-5000 (Phillips Medical Systems) and VIVID-7 (General Electric Medical Systems, USA) devices. A linear transducer with broadband frequencies in the $5-10 \mathrm{MHz}$ range is usually employed. In DVT an intact segment of femoral vein of the affected extremity was examined, and in the case of its thrombosis-femoral segment of contralateral extremity was located. In examination of patients with varicose veins we studied the extremity with the most manifestation of the disease. In case of superficial veins thrombosis, the deep veins of affected extremity were studied. The state of structures of the first and the second valves of femoral vein were assessed as the most available and reproducible for ultrasound scanning. The evaluations were carried out in standing and lying positions and with using functional tests (Valsalva's test, tests with proximal and distal manual compression). In order to avoid the provocation of $\mathrm{PE}$, these tests were conducted in patients with occlusive thrombosis of deep veins of calf. The tests were short and low-intensity.
Functions of venous valves were assessed placing transducer of the scanner under the visual control immediately above valve leaflets area. D-dimer level was assessed with coagulometer Sysmex CA-1500 with immunoturbidimetric method (D-dimer test Siemens Innovance, Germany).

\section{Statistics}

Statistical analyses were performed using Statistica 10 (StatSoft, Tulsa, OK, USA). The clinical characteristics of patients are presented by methods of descriptive statistics. A Shapiro-Wilk test was performed to assess normal distribution of the data. Data were expressed as mean $\pm \mathrm{SD}$ values. Continuous variables were analyzed with the independent Student's $t$ test or Mann-Whitney U test for nonparametric variables when appropriate. Interrelations of parameters were checked using Spearman's rank correlation coefficient. Comparisons of categorical variables were performed with the $\square 2$ test. A value of $\mathrm{P}<0.05$ was accepted as representing a significant difference.

\section{Results}

Valve leaflets of femoral vein were visualized in the lying position as thin echogenic strips making oscillations of different amplitude. They move away from vein wall by inspiration and press to the vein by expiration. Probably that is the way the blood evacuation from valve sinuses is performed. The area of valve sinus in supine position in the normal condition does not contain echogenic particles.

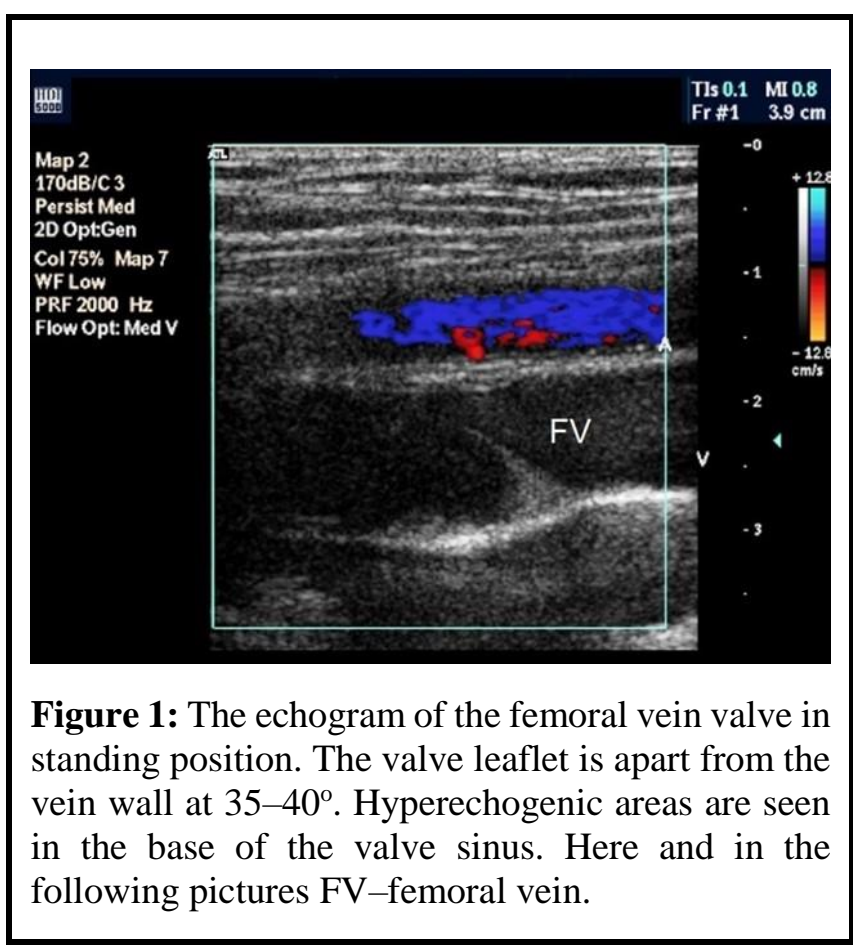


Citation: Ignatyev IM, Fomina EE. Method of Preventive Ultrasound Diagnosis of Venous Thrombosis. Int J Gen Med Surg 2017; 1: 105.

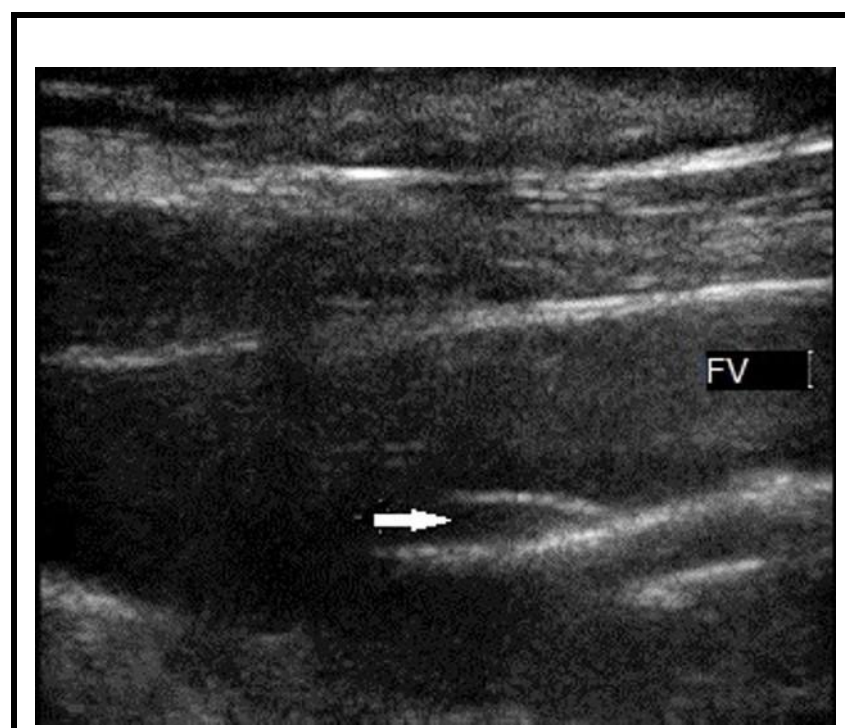

Figure 2: Phenomenon of the 1st degree spontaneous echo contrast. The echogram of the venous valve before the functional test. Echopositive particles are seen in the base of the valve sinus (arrow).

In all patients of control group ( $\mathrm{n}=52$ ), in resting state in the upright position the valves of superficial and deep veins are constantly open, their leaflets are at the angle of 30-40 degrees to the wall of the vein.
Valve leaflets perform oscillations in the vein lumen with a high frequency and a small amplitude of 515o. At Valsalva's test valve leaflets close up in the vein center. In the niches of valve sinuses multiple non-homogeneous echogenic particles are detected. It is caused by accumulation of blood cells and its turbulence (effect of spontaneous echo contrast) (Figure 1).

We also observed a similar event in lying position. We differed two degrees of spontaneous echo contrast. The 1st degree is characterized by echogenic formation occupying no more than $1 / 3$ of valve sinus and completely disappearing while performing functional tests (Figure 2). At the 2nd degree echogenic formation occupying more than $1 / 2$ of valve sinus is visualized. It reduces its intensity during functional tests. Valve leaflet is thickened to $0.81 \pm 0.12 \mathrm{~mm}$ (Figures $3 \mathrm{a}$ and $3 \mathrm{~b}$ and Table 1). Thrombosis of venous sinus with leaflet fixation was determined in seven patients (Figures $4 a$ and $4 b$ ). Degree and frequency of spontaneous echo contrast are presented in Table 1.

D-dimer values in patients of different groups and depending on degree of spontaneous echo contrast are presented in Tables 2-4.

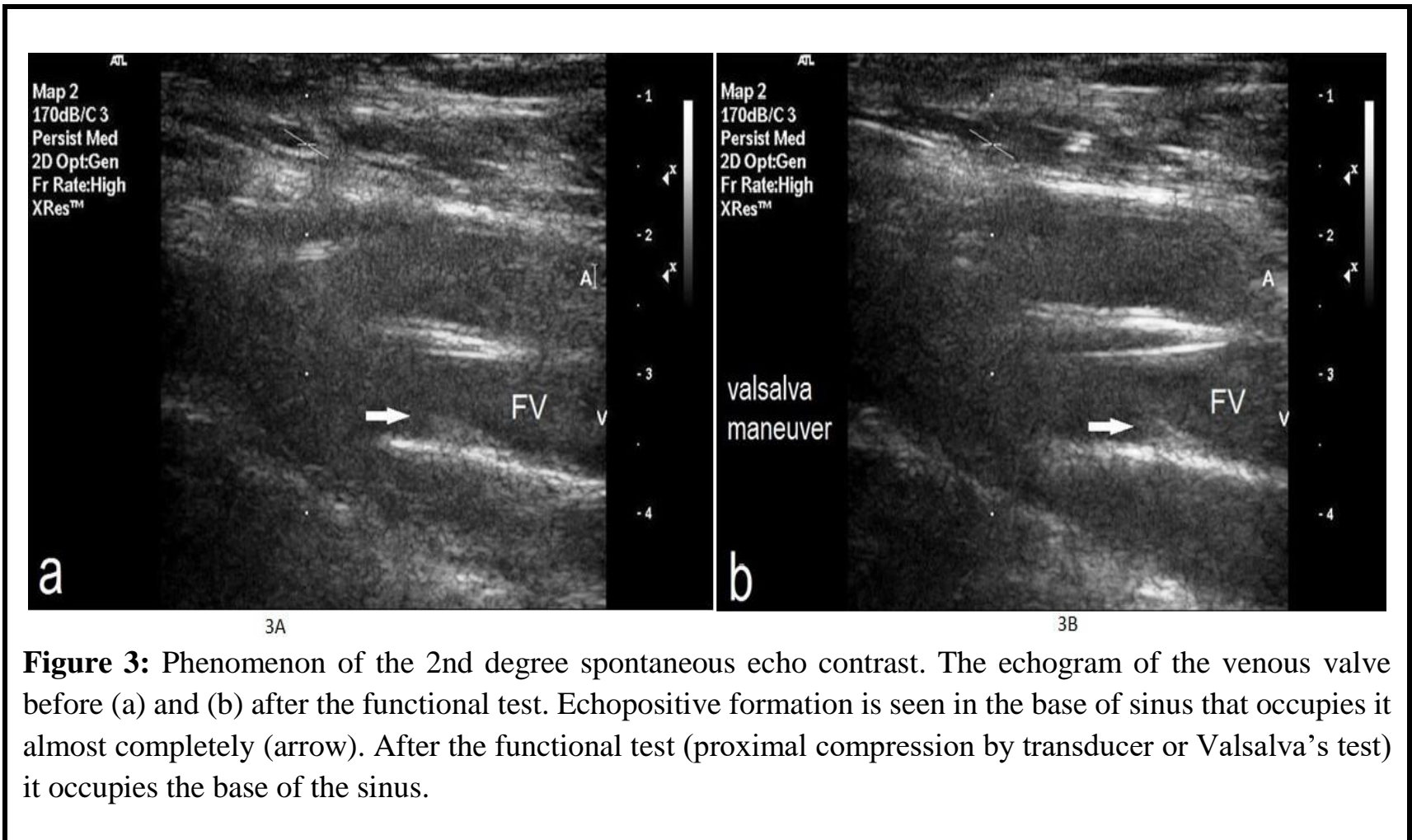


Citation: Ignatyev IM, Fomina EE. Method of Preventive Ultrasound Diagnosis of Venous Thrombosis. Int J Gen Med Surg 2017; 1: 105.

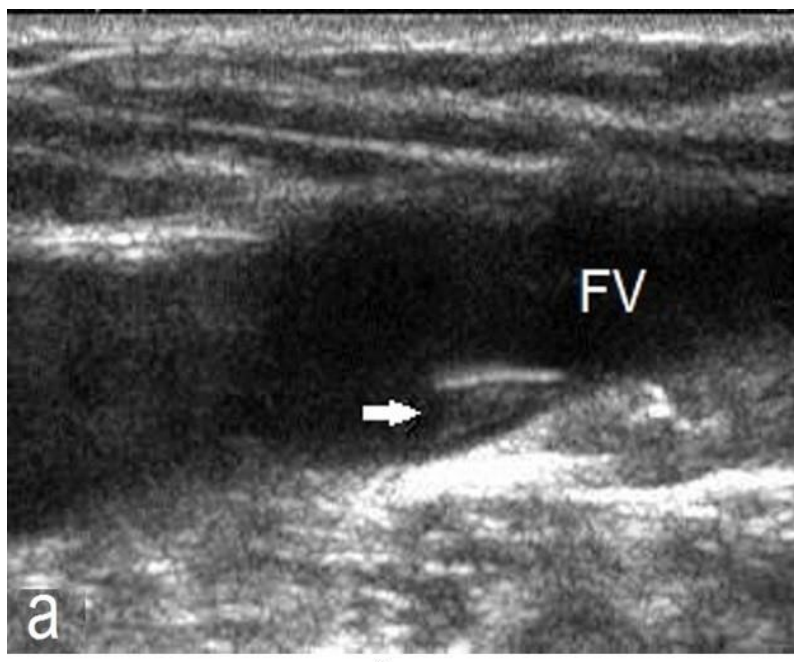

A

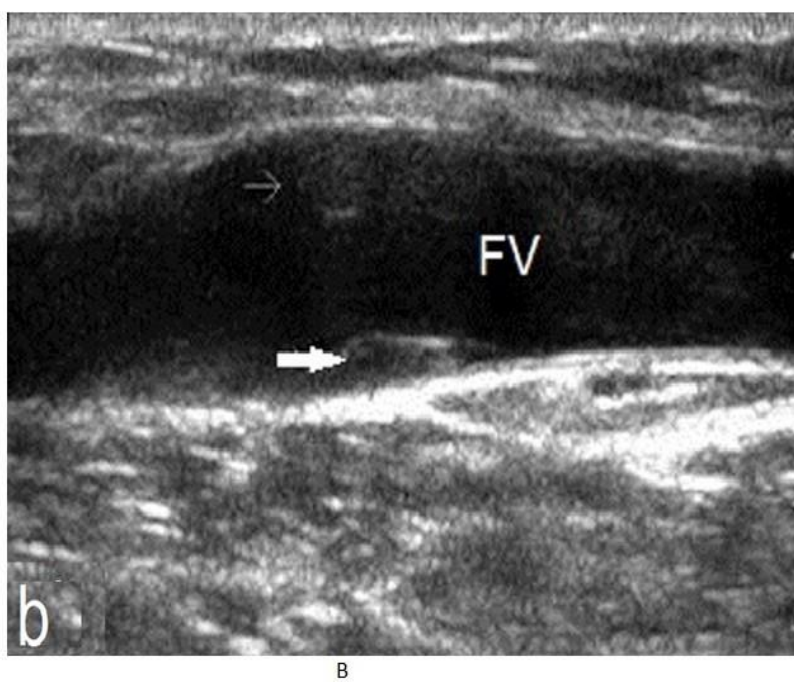

Figure 1: The echogram of the sinus thrombosis of the venous valve before (a) and (b) after the functional test. Echopositive formation is defined and it occupies the whole sinus and comes out of its borders (arrow). Valve cusp is fixed and doesn't react to functional tests.

Table 1: Valve leaflet sizes depending on degree of spontaneous echo contrast.

\begin{tabular}{|c|c|c|c|}
\hline Parameters & $\begin{array}{c}\mathbf{1}^{\text {st }} \text { degree } \\
(\mathbf{n = 1 0 7})\end{array}$ & $\begin{array}{c}\mathbf{2}^{\text {nd }} \text { degree } \\
(\mathbf{n = 1 2 7})\end{array}$ & P value \\
\hline Thickness, mm & $0.52 \pm 0.14$ & $0.81 \pm 0.12$ & $<0.05$ \\
& $0.39-0.65$ & $0.63-0.92$ & \\
\hline Length, cm & $1.12 \pm 0.18$ & $1.16 \pm 0.2$ & $>0.05$ \\
& $0.85-1.32$ & $0.83-1.42$ & \\
\hline
\end{tabular}

Table 2: Degree and frequency of spontaneous echo contrast.

\begin{tabular}{|c|c|c|c|c|c|c|}
\hline $\begin{array}{c}\text { Subgroups of } \\
\text { patients }\end{array}$ & $\begin{array}{c}1^{\text {st }} \text { group } \\
(\mathrm{n}=146)\end{array}$ & $\begin{array}{c}\mathbf{2}^{\text {nd }} \text { group } \\
(\mathrm{n}=\mathbf{1 0 8})\end{array}$ & $\begin{array}{c}3^{\text {rd }} \text { group } \\
(\mathrm{n}=52)\end{array}$ & $\begin{array}{c}P \text { in } \\
\text { comparison } \\
\text { of } 1^{\text {st }} \text { and } \\
2^{\text {nd }} \text { group } \\
\end{array}$ & $\begin{array}{c}P \text { in } \\
\text { comparison } \\
\text { of } 1^{\text {st }} \text { and } \\
3^{\text {rd }} \text { group }\end{array}$ & $\begin{array}{c}P \text { in } \\
\text { comparison } \\
\text { of } 2^{\text {nd }} \text { and } \\
3^{\text {rd }} \text { group }\end{array}$ \\
\hline $\begin{array}{l}1 \text { st degree of } \\
\text { spontaneous echo } \\
\text { contrast }\end{array}$ & $21(14.4 \%)$ & $78(72.2 \%)$ & $8(15.4 \%)$ & $<0.01$ & $>0.05$ & $<0.01$ \\
\hline $\begin{array}{l}\text { 2nd degree of } \\
\text { spontaneous echo } \\
\text { contrast }\end{array}$ & $106(72.6 \%)$ & 19 (17.6\%) & $2(3.8 \%)$ & $<0.01$ & $<0.01$ & $<0.05$ \\
\hline $\begin{array}{l}\text { Thrombosis of } \\
\text { venous sinus }\end{array}$ & $6(4.1 \%)$ & $1(0.9 \%)$ & - & $>0.05$ & - & - \\
\hline $\begin{array}{l}\text { Spontaneous echo } \\
\text { contrast and } \\
\text { thrombosis of } \\
\text { venous sinus are not } \\
\text { determined } \\
\end{array}$ & $13(8.9 \%)$ & $10(9.3 \%)$ & $42(80.8 \%)$ & $>0.05$ & $<0.01$ & $<0.01$ \\
\hline
\end{tabular}


Citation: Ignatyev IM, Fomina EE. Method of Preventive Ultrasound Diagnosis of Venous Thrombosis. Int J Gen Med Surg 2017; 1: 105.

Table 3: Level of D-dimer in the groups of examined patients.

\begin{tabular}{|c|c|c|c|c|c|c|}
\hline D-dimer level & $\begin{array}{c}\mathbf{1}^{\text {st }} \text { group } \\
(\mathbf{n = 1 4 6})\end{array}$ & $\begin{array}{c}\mathbf{2}^{\text {nd }} \text { group } \\
(\mathbf{n = 1 0 8})\end{array}$ & $\begin{array}{c}\mathbf{3}^{\text {rd }} \text { group } \\
(\mathbf{n = 5 2})\end{array}$ & $\begin{array}{c}\mathbf{P} \text { in } \\
\text { comparison } \\
\text { of 1 } \text { st } \text { and } \\
\mathbf{2}^{\text {nd }} \text { group }\end{array}$ & $\begin{array}{c}\text { P in } \\
\text { comparison } \\
\text { of } \mathbf{1}^{\text {st }} \text { and 3d } \\
\text { group }\end{array}$ & $\begin{array}{c}\text { P in } \\
\text { comparison of } \\
\mathbf{2}^{\text {nd }} \text { and } \mathbf{3}^{\text {rd }} \\
\text { group }\end{array}$ \\
\hline$<0,5 \mathrm{mcg} / \mathrm{ml}$ & $2(1.4 \%)$ & $97(89.8 \%)$ & $51(98.0 \%)$ & $<0.01$ & $<0.01$ & $>0.05$ \\
\hline $0,5 \mathrm{mcg} / \mathrm{ml}$ & $6(4.1 \%)$ & $8(7.4 \%)$ & $1(2.0 \%)$ & $>0.05$ & $>0.05$ & $>0.05$ \\
\hline$>0,5 \mathrm{mcg} / \mathrm{ml}$ & $138(94.5 \%)$ & $3(2.8 \%)$ & - & $<0.01$ & - & - \\
\hline $\begin{array}{l}\text { Quantitative } \\
\text { characteristics }\end{array}$ & $\begin{array}{c}2.76 \pm 0.12 \\
0.42-4.23\end{array}$ & $\begin{array}{c}0.32 \pm 0.20 \\
0.22-2.70\end{array}$ & $\begin{array}{c}0,26 \pm 0.03 \\
0.20-0.50\end{array}$ & $<0.01$ & $<0.01$ & $>0.05$ \\
\hline
\end{tabular}

Table 4: D-dimer level depending on the state of spontaneous echo contrast and thrombosis of venous sinus.

\begin{tabular}{|c|c|c|c|c|c|c|}
\hline D-dimer level & $\begin{array}{c}1^{\text {st }} \text { degree of } \\
\text { spontaneous } \\
\text { echo contrast } \\
(n=107)\end{array}$ & $\begin{array}{c}2^{\text {nd }} \text { degree of } \\
\text { spontaneous } \\
\text { echo contrast } \\
(n=127)\end{array}$ & $\begin{array}{c}\text { Thrombosis } \\
\text { of venous } \\
\text { sinus } \\
(n=7)\end{array}$ & $\begin{array}{c}P \text { in } \\
\text { compariso } \\
n \text { of } 1^{\text {st }} \\
\text { and } 2^{\text {nd }} \\
\text { degree }\end{array}$ & $\begin{array}{c}P \text { in } \\
\text { comparison } \\
\text { of } 1^{\text {st }} \text { degree } \\
\text { and } \\
\text { thrombosis } \\
\text { of venous } \\
\text { sinus }\end{array}$ & $\begin{array}{c}P \text { in } \\
\text { comparison } \\
\text { of } 2^{\text {nd }} \text { degree } \\
\text { and } \\
\text { thrombosis } \\
\text { of venous } \\
\text { sinus }\end{array}$ \\
\hline$<0.5 \mathrm{mcg} / \mathrm{ml}$ & $76(71.0 \%)$ & $5(3.9 \%)$ & - & $<0.01$ & $<0.01$ & $>0.05$ \\
\hline $0.5 \mathrm{mcg} / \mathrm{ml}$ & $29(27.1 \%)$ & $11(8.7 \%)$ & - & $<0.01$ & $>0.05$ & $>0.05$ \\
\hline$>0.5 \mathrm{mcg} / \mathrm{ml}$ & $2(1.9 \%)$ & $111(87.4 \%)$ & $7(100.0 \%)$ & $<0.01$ & $<0.01$ & $>0.05$ \\
\hline $\begin{array}{l}\text { Quantitative } \\
\text { characteristics }\end{array}$ & $\begin{array}{c}0.48 \pm 0.03 \\
0.40-0.62\end{array}$ & $\begin{array}{c}1.39 \pm 0.39 \\
0.90-2.50\end{array}$ & $\begin{array}{c}2.50 \pm 0.86 \\
1.51-4.00\end{array}$ & $<0.01$ & $<0.01$ & $<0.01$ \\
\hline
\end{tabular}

A direct interrelation between the degree of $2 d$ spontaneous echo contrast and D-dimer level was determined during correlation analysis in the $1^{\text {st }}$ group $(\mathrm{r}=0.89, \mathrm{P}<0.05)$.

\section{Discussion}

It is well known that the risk of venous thromboembolism increases with age, obesity, new malignant growths, previous thrombosis of deep veins and PE, antiphospholipid syndrome, pregnancy, repeated interventions and thrombophilia states [9].

Various clinical presentations of deep vein thrombosis should be verified with objective diagnostics methods. Nowadays they are USDS and laboratory tests. D-dimer study is paid much attention in laboratory diagnostics of deep vein thrombosis. It is a specific marker of intravascular fibrin accumulation and one of terminal products of plasmin degradation of stabilized fibrin [10]. Excess of D-dimer concentration in blood for more than $0.5 \mathrm{mcg}$ (microgram) $/ \mathrm{ml}$ is one of the most reliable markers of deep vein thrombosis, its sensibility varies from $87 \%$ to $96 \%$. One of the main disadvantages of the method is its low specificity from $39 \%$ to $64 \%$, that limits its application in the practice as isolated way without instrumental methods of diagnostics $[11,12,13]$.

Recently, an important role of thrombophilia states such as inherited or acquired changes in hemorheology and hemostasis has been noted in development of deep veins thrombosis. They create a high risk of thrombosis development and recurrence [14]. Occurrence of different kinds of hematogenic thrombophilia in patients with thrombosis of deep veins amounts to 60$70 \%[15,16]$. General frequency of thrombophilia is from $8 \%$ to $11 \%$ of the population [17].

Thrombosis are more often primarily located in the venous valve sinuses and spread along the vein $[18,19,20]$. The area of valve sinus is in hemodynamic unfavourable conditions. According to research of Sevitt [21] and Boisseau et al. [22], turbulent blood flow in the sinus area promotes stasis of blood cells (mostly erythrocytes). In case of imbalance between coagulative and fibrinolytic systems a thrombus develops in the niche of valve sinus and it spreads along the vein (Figure 5) [19]. Obviously, this balance may depend on 
coagulative blood activity and presence of any kind of thrombophilia.

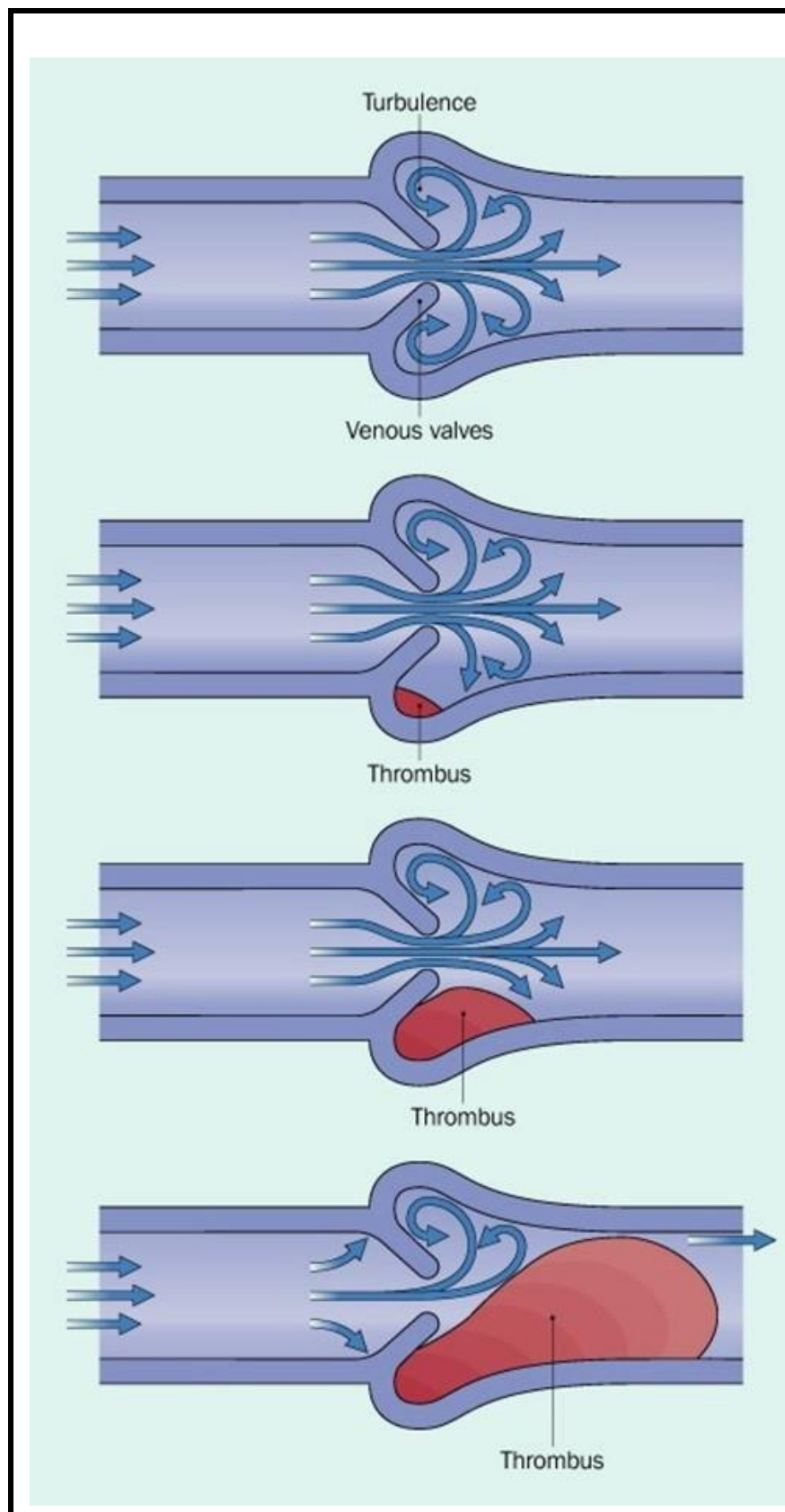

Figure 5: Origin of thrombus and its propagation (according to Tan et al., [23]).

In our view, the $1^{\text {st }}$ degree of spontaneous echo contrast phenomenon in the area of valve sinuses indicates enhanced thrombogenicity. There is a significant increase of frequency of this phenomenon (up to $72.2 \%$ ) in patients with varicose veins compared to control group of healthy persons $(\mathrm{P}<0.01)$. A fact of valve damage of varicose veins, affected by hypoxia, infiltration of vein wall and valve leaflets by macrophages and monocytes with endothelium disfunction and induction of its coagulative activity is widely known [23-25]. It is possible that the fact of spontaneous echo contrast phenomenon of the 1st degree is an ultrasound reflection of similar processes in the area of deep veins valves.

The 2nd degree of spontaneous echo contrast is characterized as pathology. We believe that the phenomenon is a prethrombosis state that is proved by the following facts. Firstly, it is known that an inflammatory process with involved vein wall and valve leaflet is one of the signs of venous thrombosis. A significant thickness of valve leaflet in the $2 \mathrm{~d}$ degree of spontaneous contrast in comparison to the $1 \mathrm{st}(\mathrm{p}<0.05)$ is an indirect confirmation of inflammatory progressing in sinus valve area (Table 1). Secondly, it is a prominent increase of the $2 \mathrm{~d}$ degree spontaneous contrast frequency $(p<0.01)$ in patients of the $1^{\text {st }}$ group with verified venous thrombosis in comparison to the $2^{\text {nd }}$ and $3^{\text {rd }}$ groups (Table 2). Besides, this fact confirms a significant increase of $\mathrm{D}$-dimer level $(\mathrm{P}<0.01)$ that is the most sensitive laboratory indication of venous thrombosis when comparing the $2 \mathrm{~d}$ degree to the $1^{\text {st }}$ degree (Table 3). The data of Table 4 also show that we didn't observe a significant difference of abnormal Ddimer value $(p>0.05)$ in the $2 d$ degree of spontaneous echo contrast and thrombosis of valve sinus as an initial stage of thrombus. It proves a high informative level of spontaneous echo contrast test. A high correlation $(\mathrm{r}=0.89 ; \mathrm{p}<0.05)$ between the $2 \mathrm{~d}$ degree and $\mathrm{D}$-dimer value in the $1^{\text {st }}$ group also confirms that this phenomenon is a prethrombosis state.

We visualized the disappearance of spontaneous contrast on contralateral extremity in patients with DVT on the 3-4 day of disease on the background of anticoagulant therapy. This phenomenon can be used as monitoring of efficiency of treatment.

\section{Conclusions}

Thus, ultrasound examination of valve sinuses is a simple, available and reproducible method of screening, and probably may be used for preventive diagnostics of acute venous thromboses. For this reason, it is possible to form risk groups of deep veins thrombosis and perform timely prevention of this pathology. Undoubtedly, further investigations in this area are necessary. To assess clinical significance of spontaneous echo, contrast a monitoring of a risk group is required. In our opinion, the comparison of ultrasound research and blood test in thrombophilia is the most promising.

\section{References}


1. Russian clinical recommendations on diagnostics, treatment and prevention of venous thromboembolic complications. Flebologia [Phlebology] 2015; 9: 52.

2. Prevention and treatment of venous thromboembolism. International Consensus Statement. Int Angiol 2013; 32: 115.

3. Coiteux I, Mazzolai L. Deep venous thrombosis: epidemiology, risk factors and natural history. Schweiz Rundsch Med Prax 2006; 95: 455-459.

4. Cushman M. Epidemiology and risk factors for venous thrombosis. Semi Hematol 2007; 44: 62-69.

5. Meissner MH. The epidemiology of and risk factors for acute deep venous thrombosis. In: Gloviczki P. Handbook of Venous Disorders. 3rd edn. London: Hodder Arnold, 2009; pp:94 -104 .

6. Vazquez SR, Freeman A, VanWoerkom RC, et al. Contemporary issues in the prevention and management of postthrombotic syndrome. Ann Pharmacother 2009; 43: 1824-1835.

7. Heit JA. The epidemiology of venous thromboembolism in the community: implications for prevention and management. In: Bergan JJ. The Vein Book. New York: Elsevier Inc 2007; pp: 323-330.

8. Salles-Cunha SX. Duplex ultrasound scanning for acute venous disease. In: Gloviczki P. Handbook of Venous Disorders. 3rd edn London: Hodder Arnold; 2009; pp:129-141.

9. Comerota AJ. DVT prophylaxis In: Comerota AJ, Kabnick SL, Sadick NS, eds. Deep vein thrombosis: Boca Raton FL: CRC Press. 2014; pp:17-24.

10. Nielsen JD. D-dimer as biomarker for venous thromboembolism. In: Bækgaard N, Fanelli F, O'Sullivan GJ. New horizons in deep venous disease management. Turin: Edizioni Minerva Medica. 2017; pp: 36-40.

11. Dale S, Gostad GO, Brosstad F, et al. Comparison of three D-dimer assays for the diagnosis of DVT: ELISA latex and immunofiltration assay (NycoCard D-dimer). Thromb Haemost 1994; 7: 270-4.

12. Ginsberg JS, Wells PS, Kearson C, et al. Sensitivity and specificity of rapid wholeblood assay for D-dimer in the diagnosis of pulmonary embolism. Ann Intern Med 1998; 129: 1006-1011.

13. Palareti G, Cosmi B, Legnani C, et al. D-dimer testing to determine the duration of anticoagulation therapy. N Engl J Med 2006; 355: 1780-1789.

14. Barkagan ZS. Study on thrombophilia in modern stage. Problemy gematologii i perelivaniya krovi [Problems of gematology and blood transfusion] 2002; 1:6-7.

15. Caprini JA, Goldshteyn S, Glase CG, et al. Thrombophilia testing in patient with venous thrombosis. Eur J Vasc Endovasc Surg 2005; 30: $550-555$.

16. Tripodi A. Issues concerning the laboratory investigation of inherited thrombophilia. Mol Diagn 2005; 9: 181-6.

17. Wu O, Robertson L, Twaddle $\mathrm{S}$, et al. Screening for thrombophilia in high-risk situations: systematic review and costeffectiveness analyze. The Thrombosis: Risk and Economic Assessment of Thrombophilia Screening (TREATS) study. Health Technol Asses 2006; 10: 1-110.

18. Browse NL, Burnand KG, Irvine AT, et al. Deep vein thrombosis: pathology. Diseases of the Veins. 2d edition. New York: Oxford Iniversity Press. 1999: pp: 249-289.

19. Tan TK, Oudkerk M, van Beek EJR. Deep vein thrombosis and pulmonary embolism. In: Hallet JW, Mills JL, Earnshaw JJ, Reekers JA, eds. Comprehensive Vascular and Endovascular Surgery. Edinburgh - London New York: Elsevier Limited. 2004 pp: 625663.

20. Klitfod L. Causes of venous thrombosis. The European perspective. In: Bækgaard N, Fanelli F, O'Sullivan GJ, eds. New horizons in deep venous disease management. Turin: Edizioni Minerva Medica. 2017; pp: 50-53.

21. Sevitt S. Venous thrombosis and pulmonary embolism. Their prevention by oral anticoagulants. Am J Med 1962; 33: 703-709.

22. Boisseau MR. Valvules veineuses des members inferieurs: problemes hemodynamiques, biologiques at relations physiopathologiques. J Mal Vasc 1997; 22: 122-127.

23. Michiels C, Arnould T, Janssens D. Interactions between endothelial cells and 
Citation: Ignatyev IM, Fomina EE. Method of Preventive Ultrasound Diagnosis of Venous Thrombosis. Int J Gen Med Surg 2017; 1: 105.

smooth muscle cells after their activation by hypoxia: A possible etiology for venous disease. Int Angiol 1996; 5: 124-130.

24. Michiels C, Bouaziz N, Remacle J. Role of the endothelium and blood stasis in the appearance of varicose veins. Int Angiol 2002; 21: 1-8.
25. Dormandy JA. Pathophysiology venous leg ulceration: an update. Angiology 1997; 48: 4175.

This manuscript was peer-reviewed

Mode of Review: Single-blinded

Academic Editor: Dr. Mina T Kelleni

Copyright: (92017 Ignatyev IM, et al. This article is distributed under the terms of the Creative Commons Attribution 4.0 International License (http://creativecommons.org/licenses/by/4.0/), which permits unrestricted use, distribution, and reproduction in any medium, provided you give appropriate credit to the original author(s) and the source, provide a link to the Creative Commons license, and indicate if changes were made. 